University of Nebraska - Lincoln

DigitalCommons@University of Nebraska - Lincoln

2019

\title{
A NEW PEST SPECIES OF RESSELIELLA (DIPTERA: CECIDOMYIIDAE) ON SOYBEAN (FABACEAE) IN NORTH AMERICA, WITH A DESCRIPTION OF THE GENUS
}

\author{
Raymond Gagne \\ Junichi Yukawa \\ Ayman K. Elsayed \\ Anthony J. McMechan
}

Follow this and additional works at: https://digitalcommons.unl.edu/entomologyfacpub

Part of the Entomology Commons

This Article is brought to you for free and open access by the Entomology, Department of at DigitalCommons@University of Nebraska - Lincoln. It has been accepted for inclusion in Faculty Publications: Department of Entomology by an authorized administrator of DigitalCommons@University of Nebraska - Lincoln. 


\section{A NEW PEST SPECIES OF RESSELIELLA (DIPTERA: CECIDOMYIIDAE) ON SOYBEAN (FABACEAE) IN NORTH AMERICA, WITH A DESCRIPTION OF THE GENUS}

urn:1sid:zoobank.org:pub:E94E2A94-0253-4593-A757-DA57A08C6178

\section{Raymond J. Gagné, Junichi Yukawa, Ayman K. Elsayed, and Anthony J. McMechan}

(RJG) Systematic Entomology Laboratory, Agricultural Research Service, U.S. Department of Agriculture, c/o Smithsonian Institution MRC-168, P.O. Box 37012, Washington, DC 20013-7012, USA (corresponding author, raymond.gagne@ars.usda. gov); (JY) Entomological Laboratory, Faculty of Agriculture, Kyushu University, Fukuoka 819-0395, Japan (jzs02305@nifty.com); (AKE) Department of Applied Entomology, Faculty of Agriculture, Alexandria University, Alexandria, Egypt, presently in Laboratory of Systems Ecology, Faculty of Agriculture, Saga University, Saga 840-8502, Japan (ayman.khamis77@gmail.com; (AJM) University of Nebraska - Lincoln, Eastern Nebraska Research and Extension Center, 1071 County Road G, Ithaca, NE 68033, USA (justin.mcmechan@unl.edu

(RJG) urn:lsid:zoobank.org:author:581F6F92-83AA-476E-A5CE-A1B814D925E8

(JK) urn:lsid:zoobank.org:author:989FF55B-6273-4B73-B739-865406449BAE

(AKE) urn:lsid:zoobank.org:author:21B0814A-3955-463D-817F-9E2F73764E9E

(AJM) urn:lsid:zoobank.org:author:996A9F8D-D941-4255-945C-F86804FF4A33

Abstract.-A new species, Resseliella maxima Gagné, is reported that feeds on the lower stems of soybean, Glycine max (L.) Merr. (Fabaceae) in Nebraska, Iowa, South Dakota and Minnesota. It is described and illustrated and compared in detail with other Resseliella spp. DNA data support its status as a new species. A general description is given for Resseliella.

Key Words: $\quad$ gall midges, Cecidomyiinae, Glycine max

$$
\text { DOI: 10.4289/0013-8797.121.2.168 }
$$

A new species of gall midge (Diptera: Cecidomyiidae) was recently discovered feeding on the stems nearest the base of soybean, Glycine max (L.) Merr. (Fabaceae) in Nebraska, Iowa, South Dakota and Minnesota. Externally, infested areas of the stems were dark brown or black. Dissection of infested plants revealed orange larvae feeding within and at the leading edge of these darkened areas (Fig. 1). Initial feeding appeared to be confined to the phloem with larvae moving into the xylem and pith over time. Since 2011 this cecidomyiid has been associated with hail-damaged or disease-compromised soybean plants. 
Signs of larval infestation occurred at the end of the growing season in late August so raised little concern about economic losses. In 2018 visible signs of dead or dying plants infested with the soybean gall midge were observed in late June. A portion of the fields surveyed in 2018 had significant levels of damage with the greatest frequency of dead plants at the field edge, dissipating with distance towards the center of the field. In addition, heavily impacted areas were often next to waterways and ditches with dense vegetation, suggesting that such areas may serve as refugia for overwintering larvae. Symptomatic soybean plants were submitted to plant diagnostic clinics in $\mathrm{Ne}$ braska, Iowa and South Dakota for plant diseases. A number of plant pathogens were found; however, a portion of plants that were submitted had no detectable plant diseases, raising concerns about the status of this insect as a primary pest of soybean.

The new species belongs to Resseliella, a cosmopolitan genus of 56 known species. A list with their hosts can be found in Gagné and Jaschhof
(2017). Most species have been reared but some are known only from specimens caught in flight. The genus is anatomically rather uniform in gross aspect and has not yet undergone a critical review. Nonetheless, specific-level attributes of both sexes, pupae and larvae are available and elucidated here. Many species live under bark or in flower heads, but some form simple galls, e.g., swellings of midribs or simple blister galls of tuliptree (Magnoliaceae) (Gagné 1989). Important pest species include three species from Japan, Resseliella soya (Monzen) that lives inside leaf veins and petioles of soybean, Resseliella yagoi Yukawa and Sato that feeds in pears (Rosaceae), and Resseliella resinicola Sanui \& Yukawa in resin of cryptomeria (Taxodiaceae), and also the European Resseliella oculiperda (Rübsaamen) that attacks fresh grafts of fruit trees, the South African Resseliella proteae Gagné that lives in flowerheads of proteas (Proteaceae) and the Australian Resseliella xanthorrhoeae Kolesik that feeds at the base of stems of dianellas
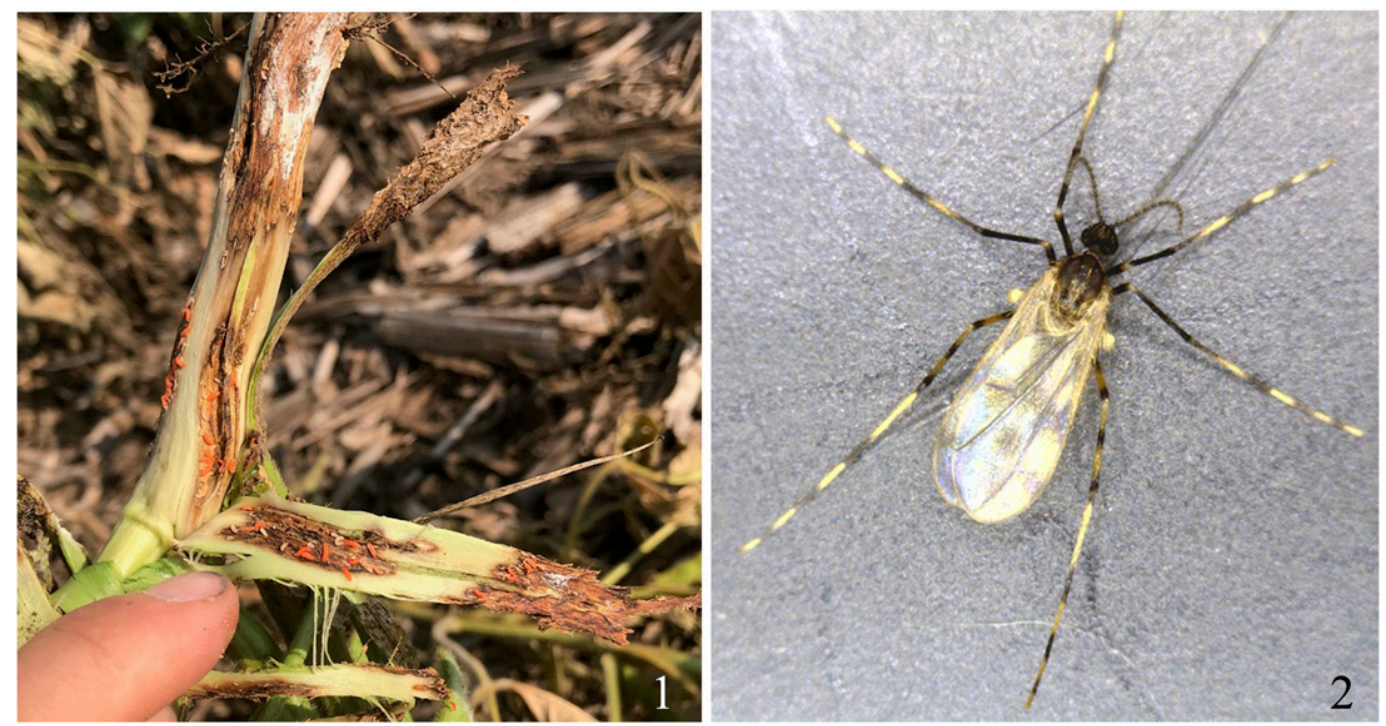

Figs. 1-2. Resseliella maxima. 1, Larvae in soybean stem. 2, Adult female. 
(Xanthorrhoaceae). The last-named species lives in association with a fungus as does the new species (Kolesik \& Baker 2013).

Gall midge larvae have piercing-sucking mouthparts and feed on a liquid diet. Upon reaching maturity all Resseliella larvae, including species that live inside plants, drop to the soil where they pupate. Adults emerge the same or the next year depending on the number of generations per year. Adults are easily keyed to genus in the key to genera in Gagné (2018), a main character being their robust and distinctively shaped claws with slightly decumbent tips (Figs. 6-7). Perhaps half the species have strongly marked antennae, wings and legs. The pattern on the antennae and legs are stereotypical but the more complicated and easily obscured pattern on the wings appears to differ among species. Larvae are distinctive for the two large lobes on the terminal segment that each bear a short-corniform papilla apically and one setose papilla medially at about midlength (Figs. 23-24).

The provenance of the new species, whether native or alien, is unknown. Because it has only recently been discovered, it might have switched host from another plant, possibly a less important native legume. Resseliella soya is associated with soybean in Japan but lives inside leaf tissue or stems and has no fungal associates. We show here that it is a distinct species morphologically and genetically.

\section{Materials And Methods}

On August 1, 2018, emergence cages were placed over cecidomyiid-infested soybean plants at Eastern Nebraska Research and Extension Center. Within 24 hours adults were observed flying in cages and individuals continued to emerge through August 19. Third instars and adults obtained there were mounted for study in Canada balsam using tech- niques outlined in Gagné (1989). A glossary of adult morphological terms can be found in Gagné (2018) and anatomy of the third instar follows Gagné (1989). Drawings were made by RJG with the use of a camera lucida attached to a Wild phase contrast microscope. The holotype and paratypes are deposited in the insect collection of the National Museum of Natural History in Washington, DC (USNM).

Total DNA was extracted from the whole body of three third instars each of Resseliella soya and the new species found feeding on lower stems of G. max in Nebraska. A 472bp fragment of the mitochondrial gene cytochrome oxidase subunit I (COI) was sequenced and aligned following Elsayed et al. (2017), using the following primer set: Forward: J-1718 (5'- GGA GGA TTT GGA AAT TGA TTA GTT CC-3') (Simon et al. 1994) and reverse: COIA (5-CCC GGT AAA ATT AAA ATA TAA ACT TC-3) (Funk et al. 1995). The sequences obtained were compared using MEGA (version 6.0) (Tamura et al. 2013) and deposited in the DNA Data Bank of Japan (DDBJ), European Molecular Biology Laboratory (EMBL), and GenBank nucleotide sequence databases as accession numbers LC437337-LC437339 and LC437340 LC437342 for $R$. soya and $R$. maxima, respectively.

\section{Results AND Discussion}

\section{Genus Resseliella Seitner}

Gagné and Jaschhof (2017) can be consulted for a synonymy of Resseliella. The following diagnosis lists the attributes shared by known species and can serve as a checklist for future species descriptions. It is based on a survey done for this paper of characters shared by known species in published descriptions as well as the species represented in the USNM. 

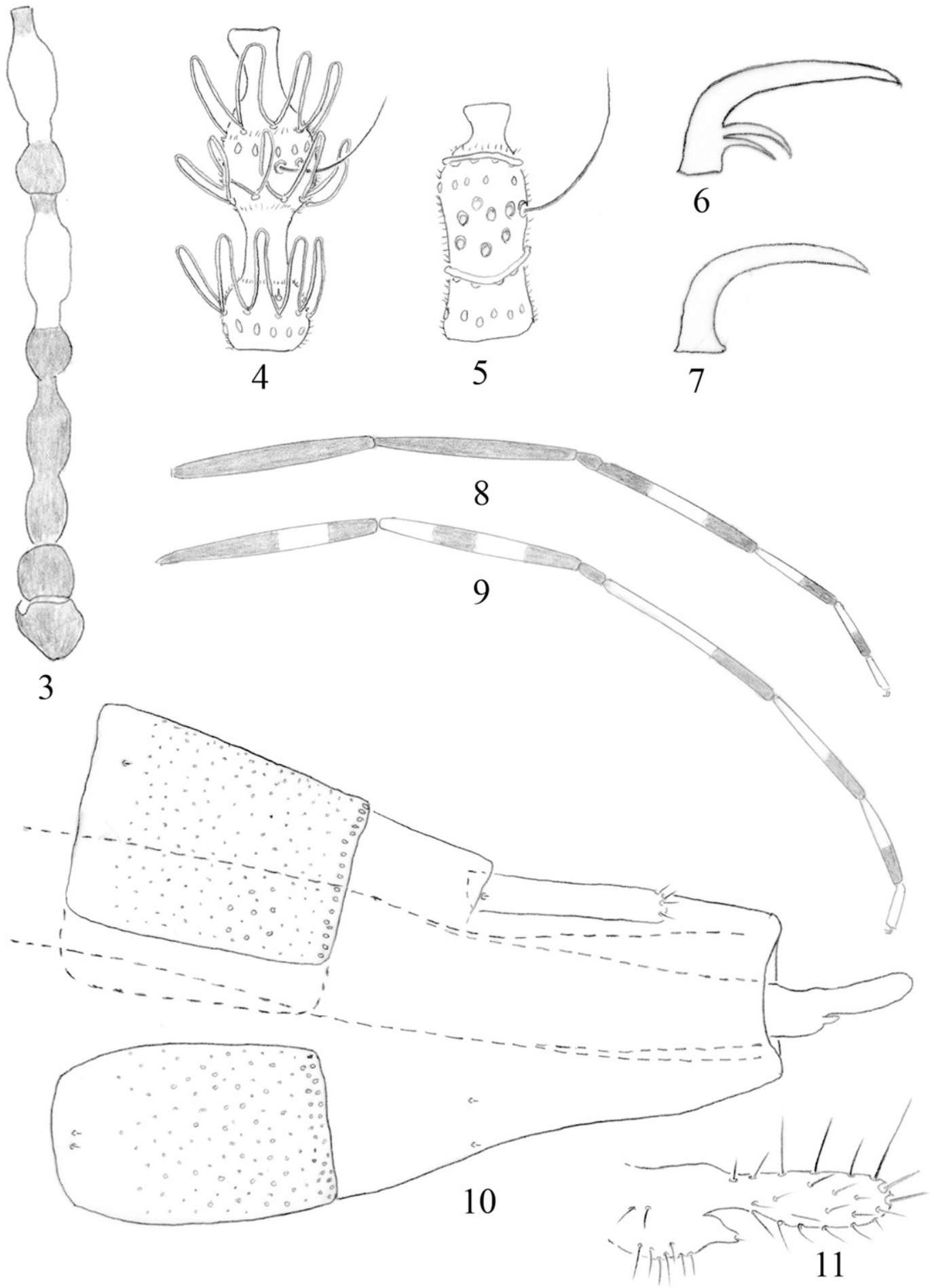

Figs. 3-11. Resseliella maxima. 3, Male antenna, scape through third flagellomere showing banding. 4, Male third flagellomere. 5, Female third flagellomere. 6, Foreclaw. 7, Midclaw. 8, Foreleg showing banding. 9, Hindleg showing banding. 10, Female abdomen, seventh segment to end (ventrolateral). 11, Detail of ovipositor terminus (lateral). 
Adult (Fig. 2). Body in life uniformly light to dark brown or additionally with antennae and legs light- and dark-banded and wings variously light- and dark patterned. Head: Eyes connate with long eye bridge at vertex; facets circular, closely approximated throughout. Occiput with dorsal protuberance bearing 2-3 long setae apically. Antenna: scape with sparse setae ventrally; occiput ringed with sparse setae; 12 flagellomeres, 12 th usually with a narrow apical prolongation; male flagellomeres (Fig. 4) binodal, first node of each with one circumfilum, second with two, circumfila all with uniform moderately long loops; female flagellomeres (Fig. 5) cylindrical, necks bare, about 1/4 length of nodes. Frons with 4-6 strong setae on each side. Labella narrow in frontal view, broad in lateral view, with several strong setae. Palpus 4-segmented with scattered setae, without scales.

Thorax: Scutum with 4 discrete longitudinal rows of setae. Scutellum with group of setae on each side. Pleura with sparse scales on anepisternum, setae on anepimeron, remaining pleura bare. Wing (Fig. 2): $\mathrm{C}$ broken at juncture with $\mathrm{R}_{5} ; \mathrm{R}_{5}$ curved apically to join $C$ posterior to wing apex; Rs incomplete, closer to arculus than to apex of $\mathrm{R}_{1}$; wing fold evident; $\mathrm{M}_{4}$ and $\mathrm{CuA}$ forming a fork. Legs (Figs. 2, 8-9): slender, elongate; acromere: claws (Figs. 6-7) robust, strongly bent near basal third, and with slight downward bend near apex, always toothed on foreleg, rarely with additional, finer tooth, mid- and hindclaws all toothed or all simple.

Male abdomen (Fig. 12): Tergites 1-6 entire, rectangular, with single, closelyset row of setae along posterior margin, several lateral setae, a pair of widely spaced anterior trichoid sensilla, and elsewhere mostly covered with scales; tergites 7-8 only about a third as long as tergite 6 , a pair of trichoid sensilla anteriorly the only vestiture except for a few short, posterolateral setae on tergite 7. Sternites $2-7$ with mostly single row of posterior setae, 2-3 rows of setae mixed with a few scales near midlength, these becoming more extensive posteriorly on sternites 4-7 to reach posterior row of setae, and pair of closely set anterior trichoid sensilla; sternite 7 additionally with double row of posterior setae; sternite 8 narrower than sternite 7 , with setae and scales on posterior half and the pair of trichoid sensilla widely spaced. Terminalia (Figs. 13-16): cerci convex apically, about as long as hypoproct but often skewed in preparations, with sparse setae along margin; hypoproct subrectangular, slightly to deeply concave apically, usually concave laterally, microtrichose on both surfaces, with 3-4 pairs of short apicoventral setae; aedeagus about as long as hypoproct, gently tapered to rounded apex, with pair of asetose papillae on each side; gonocoxite ovate to bulbous in dorsal view, with obtuse mediobasal lobe in some species; gonostylus more or less tapered, setulose basally, glabrous and ridged beyond, with scattered, short setae.

Female abdomen (Figs. 10-11) Tergites 1-7 generally as for male 1-6 but larger; tergite 7 narrower than 6 th; tergite 8 much narrower than 7 th with short terminal setae and anterior pair of trichoid sensilla the only vestiture. Sternites 2-7 generally as for male; sternite 8 undefined but a pair of widely spaced trichoid sensilla evident. Ovipositor protrusible, elongate, cylindrical, surface of both eversible and protrusible parts minutely spiculose and sparsely and uniformly covered with short setae, except bare dorsally immediately preceding cerci; protrusible part without lateral sclerites and 3-7 times the length of the 7th tergite; cerci elongate-ovoid with scattered long and short setae, one pair near terminus thickened, with sockets 

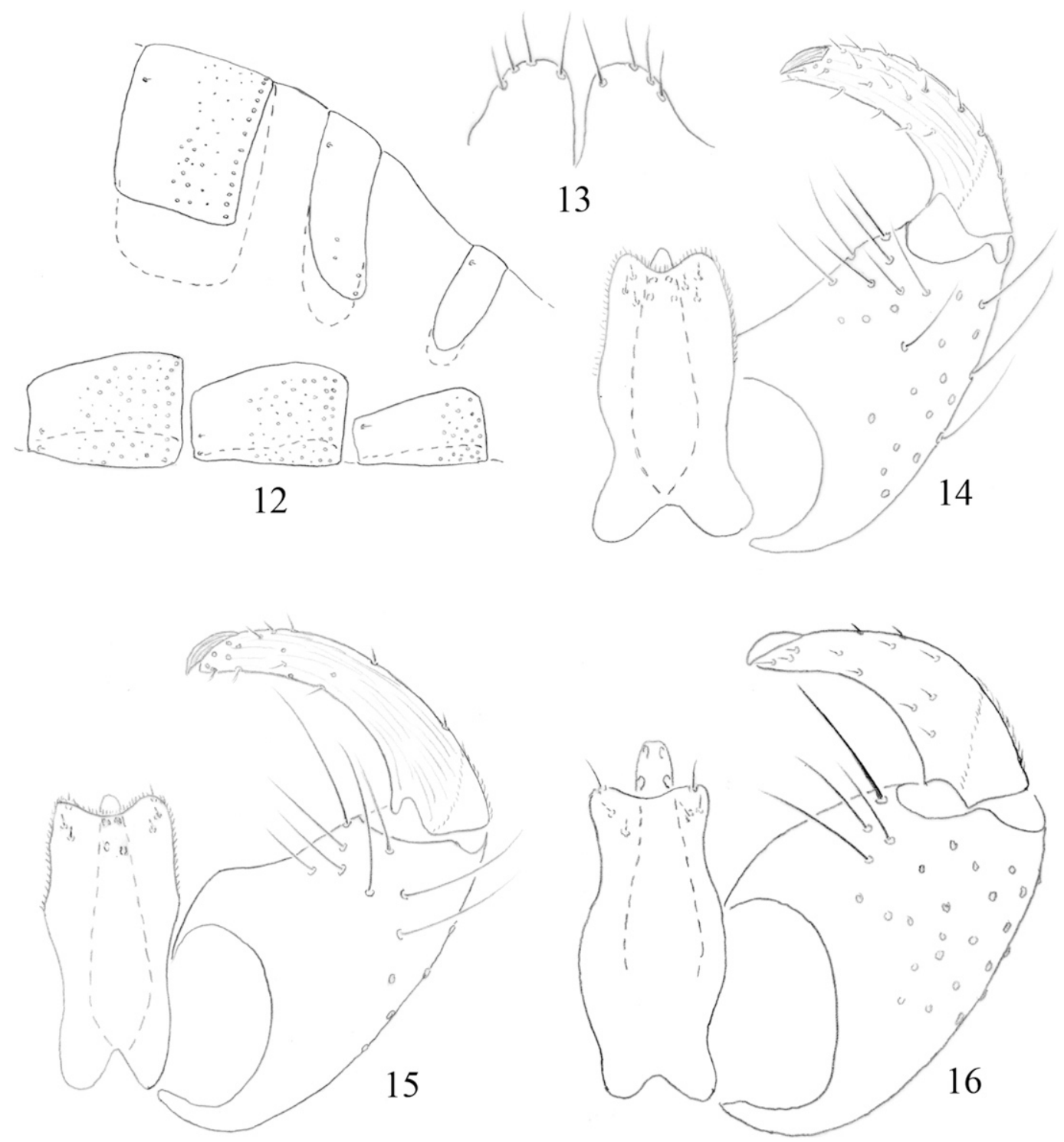

Figs. 12-14. Resseliella maxima. 12, Male abdomen, sixth through eighth segments (lateral). 13, Cerci (dorsal). 14, Terminalia, cerci not shown (dorsal). Fig. 15, Resseliella soya, same. Fig. 16, Resseliella clavula, same.

larger than those of remaining setae; hypoproct much shorter than cerci with two apical setae.

Pupa. Vertex convex, each side with long seta on raised base (Fig. 17). Antennal bases with short, obtuse anteromedial angles and short apicoventral umbo (Fig. 17) anteroventrally. Face smooth. Pro- thoracic spiracles elongate, pointed. Abdominal spiracles sessile. Terga 2-8 each with about 5- to 6-branched anterior spines (cf. Kolesik \& Baker 2013: fig. 6b) or with 6 simple spines (cf. Yukawa \& Sato 2009: fig. 4e), dorsum elsewhere and pleura and sterna uniformly covered with short spicules. 


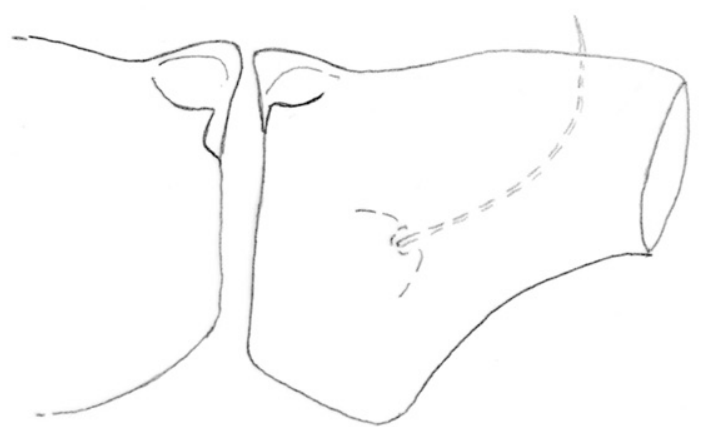

17

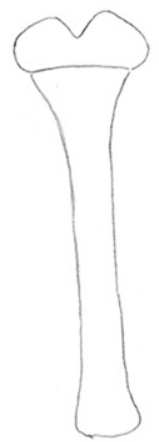

18

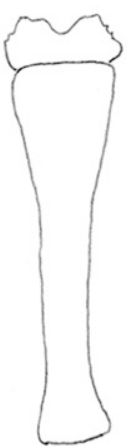

19

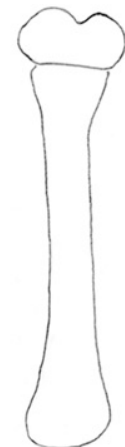

20

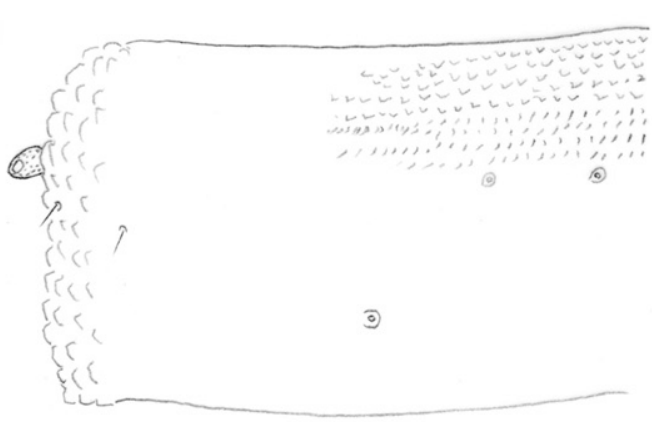

21

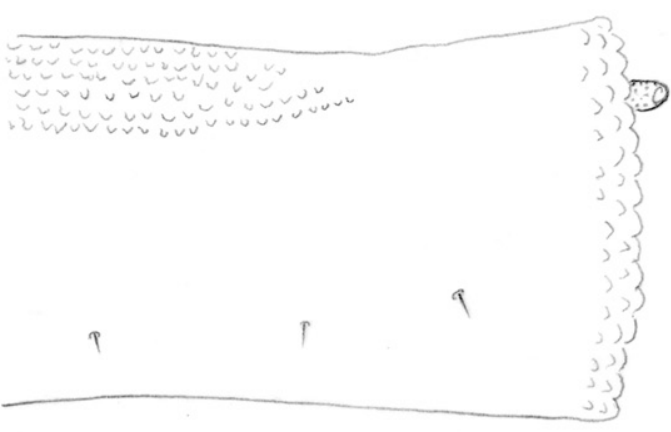

22

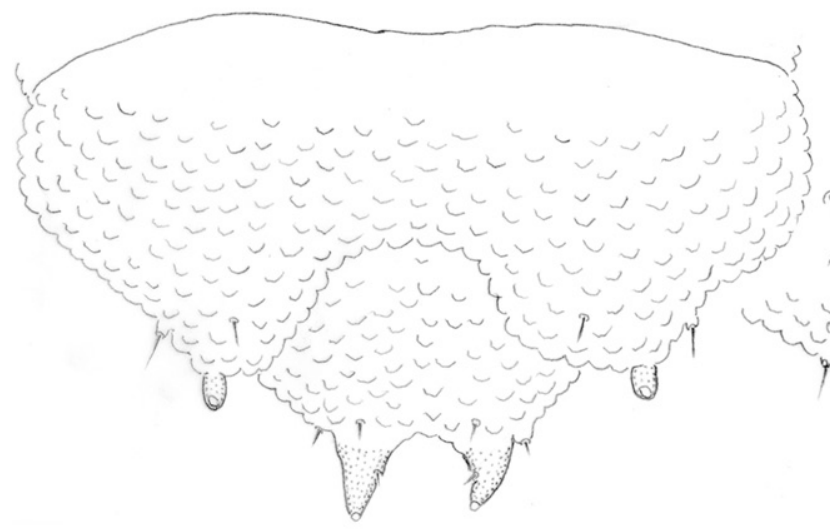

23

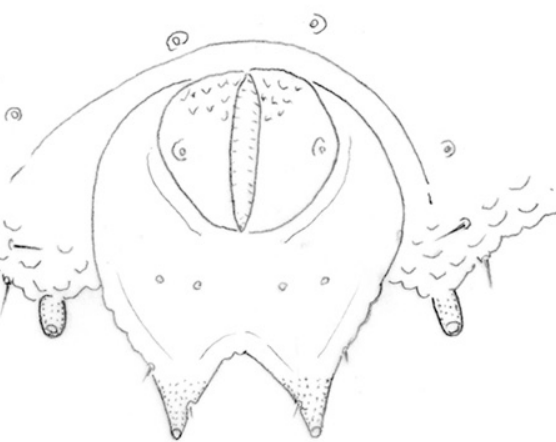

24

Fig. 17. Resseliella liriodendri, pupal antennal bases and vertexal papilla. Fig. 18, Resseliella soya, larval spatula. Fig. 19, Resseliella clavula, larval spatula. Figs. 20-24. Resseliella maxima. 20, Larval spatula. 21, Larval fifth abdominal segment (left half, ventral). 22, Same (right half, dorsal). 23, Larval eighth abdominal and terminal segments (dorsal). 24, Same (ventral).

Larva. Third instar: Head directed anteriorly; cephalic apodemes stout, about as long as head capsule. Antenna about twice as long as wide. Spatula (Figs. 18-20) with anterior tooth weakly to deeply emarginate apicomedially, the lobes rounded; shaft 
long, slender, parallel-sided, encroaching second thoracic segment. Spiracles laterally disposed at midlength except eighth abdominal spiracles situated at lateroposterior end of segment and directed posteriorly. Papillae as for basic plan of Cecidomyiidi and Resseliella as outlined in Möhn (1955). Integument (Figs. 21-24) on dorsum smooth to nearly entirely pebbled, second thoracic to seventh abdominal segments with horizontal rows of tiny, rounded spicules anteromedially, rows gradually more numerous from second thoracic segment to seventh abdominal, eighth abdominal and terminal segments without spicules and mostly pebbled; venter pebbled or not as for dorsum, second thoracic to eighth abdominal segments with ventral anteromedial fields of spicules of two kinds, the more anterior rows rounded, posterior rows finer and pointed, except spicule rows of eighth abdominal segment all rounded if present; pleura pebbled. Terminal segment (Figs 23-24) dorsally partly to entirely pebbled with 6 short-setose papillae, one situated at midlength of each of 2 prominent, conical, usually pigmented, slightly dorsally recurved, posterior lobes, each lobe terminating with corniform seta; ventral surface smooth to partly pebbled or spiculose, anal slit smooth or lined with pointed spicules, perianal pads each bearing a single papilla without seta, area posterior to perianal pads bearing 4 papillae without setae.

Remarks. At least half the known species were described as having one or more of banded antennae, banded legs and mottled wings. Antennal banding is integumental but leg banding is due to the color of the covering scales that are easily lost through handling and slide preparation. Nevertheless, the pattern of banding on the antennae and legs when it does occur is usually nearly entirely similar to that of the new species (Figs. 2-3, 8-9). Mottling of the wing, however, is due to both ground color of the wing membrane and scales but, again, the scales are easily lost and the mottling of the membrane is usually faint. Although the wing mottling appears to differ among species, it is difficult to compare among species without pristine specimens.

Claws of most known species are toothed on the foreclaws and simple on the mid- and hindclaws. The few species known to have all the claws toothed are Resseliella piceae Seitner, Resseliella kadsurae Yukawa, Sato \& Xu, R. yagoi and $R$. resinicola. The toothed foreclaws of only the new species and Resseliella clavula (Beutenmüller) have an additional smaller tooth (Fig. 6).

Male cerci are set at some remove from the hypoproct on Resseliella species, so slide preparations that flatten the terminalia skew them with regard to the hypoproct. Because of this, estimates of cercal length with regard to that of the hypoproct can be inaccurate. In addition the cerci do not appear to show specific differences.

The protrusible distal half of the long ovipositor is not as stiff as in other genera with long ovipositors, perhaps abetted by the absence of lateral sclerites, so may show some accordioning. Although the structure does not lend itself to precise species measurement, its length compared to that of the seventh tergite is still a useful species character.

\section{Resseliella maxima Gagné, new species}

urn:1sid:zoobank.org:act:4BF1A716-

54A4-4C5F-92F1-B1391ED224D4

Adult. Color in life: Antenna (Fig. 3) with alternating ground color of dark and light bands; male with scape, pedicel, first flagellomere and first node and neck of each successive flagellomere dark, the remainder light, the female with basal 
third of each node and neck dark, remainder light; wing (Fig. 2) mottled with yellow and black scales reinforced by light and dark ground color; legs (Figs. 89) with alternating bands of dark and light scales, those on fore- and midlegs black except yellow at joint of femur and tibia, on middle $1 / 3$ of second tarsomere, basal $3 / 5$ of third and fourth, and all of fifth; hindleg black except yellow on third $1 / 4$ of femur, first and third $1 / 4$ of femur, basal $2 / 3$ of second, third and fourth tarsomeres and all of fifth. Frons with 5-6 setae on each side. Wing: length in males, 2.0-2.1 mm $(n=4)$; in females, 2.3-2.5 $\mathrm{mm}(\mathrm{n}=6)$. Anepimeron with 10-13 setae. Claws (Figs. 6-7) anisomorphic, foreclaws with two basal teeth, mid- and hindclaws untoothed. Male abdomen: segments 6-8 as in Fig. 12; terminalia (Figs.13-14) with gonostylus evenly and only gradually tapered. Female abdomen (Figs. 10-11): protrusible part of ovipositor 5.9-6.5 times length sternite $7(n=6)$.

\section{Pupa. Unknown.}

Larva. Third instar: Orange in life. Spatula tooth (Fig. 20) slightly emarginate. Thorax and first through seventh abdominal segments pebbled only on pleura (Figs. 21-22). Eighth abdominal and terminal segments as in Figs. 23-24.

Material examined--Holotype, male, reared from larva on soybean stem, Saunders, Nebraska, VII-7-2018, J. McMechan, deposited in USNM. Paratypes: same pertinent data as holotype, 4 males, 8 females, larvae, all deposited in USNM except 1 male, 1 female and 4 larvae deposited in Entomological Laboratory, Kyushu University, Fukuoka, Japan. Other specimens, deposited in USNM: 10 larvae, Griswold, Iowa, IX-2018, Michael Leetch; 10 larvae, VIII-2018, Iowa, Jessie Alt.

Etymology.- The name maxima means greatest, reflecting both the insect's potential importance to soybean and the host's name, G. max.
Remarks. This species is compared here with two other species of Resseliella, $R$. soya, which occurs on soybean in Japan, and $R$. clavula from Cornus florida (Cornaceae) in eastern North America, the only other species of the genus known to share with the new species a second tooth on the foreclaws.

Resseliella soya is distinct from $R$. maxima in that its gonostylus (Fig. 15) is thinner and more strongly tapered, the gonocoxite has an obtuse mediobasal lobe, the protrusible part of the ovipositor, at about three times the length of the seventh tergite, is only half the length in $R$. maxima, and the third instar differs in the more deeply emarginate spatula tooth (Fig. 18). Differences are based on a male and two females and six third instars from Oshiage, Hokuto City Hokkaido, Japan, as well as the description and illustration in Yukawa (1971). Moreover, COI mitochondrial gene segments of $R$. maxima are distinctly different from those of $R$. soya, showing an $8.5-8.7 \%$ pairwise distance.

Resseliella clavula has a more strongly tapered gonostylus (Fig. 16) and the gonocoxite is more bulbous than in either $R$. soya or $R$. maxima. The length of the ovipositor is unknown. The tooth of the third instar spatula is somewhat emarginate and also noticeably erose (Fig. 19). This rough margin of the spatula tooth is apparent on all available third instars of $R$. clavula. This species lives in a woody gall, which may possibly explain the uneven margin. These observations are based on two males from Albany, NY, one male from Stamford CT, two third instars from Hewitt, NJ, ten third instars from Richmond Hill, GA, and two third instars from Gainesville, FL.

\section{ACKNOWLEDGMENTS}

We thank Dr. Jung Wook ("Woogie") Kim, USDA-APHIS-PPQ-PHP, National 
Identification Services, for the final arrangement and labelling of the plates; Dr. Y. Nagano, Analytical Center for Experimental Sciences, Saga University, for his careful assistance with the molecular analysis; Mr. Motohiko Aoki, Local Independent Administrative Agency Hokkaido Research Organization, Donan Agricultural Experiment Station, Hokkaido 041-1201, Japan for his recent collections of $R$. soya from Hokkaido; Mike Leetch, Syngenta, Des Moines, IA, and Jessie Alt, Corteva Agrisciences, Dallas Center, IA, USA for larval specimens; and journal reviewers Netta Dorchin, Tel Aviv University, Israel, and Peter Kolesik, Adelaide, SA, Australia, for their careful reading and comments on the manuscript.

Mention of trade names or commercial products in this publication is solely for the purpose of providing specific information and does not imply recommendation or endorsement by the USDA. USDA is an equal opportunity provider and employer.

\section{Literature Cited}

Elsayed, A.K, K. Ogata, K. Kaburagi, J. Yukawa and M. Tokuda (2017) A new Dasineura species (Diptera: Cecidomyiidae) associated with Symplocos cochinchinensis (Loureiro) (Symplocaceae) in Japan. Japanese Journal of Systematic Entomology 23: 81-86.

Funk D.J., D.J. Futuyma, G. Orti and A. Meyer (1995) Mitochondrial DNA sequences and multiple data sets: a phylogenetic study of phytophagous beetles (Chrysomelidae: Opharaella). Molecular Biology and Evolution 12: 627-640.

Gagné, R.J. 1989. The Plant-Feeding Gall Midges of North America. Cornell University Press, Ithaca, New York. xi \& 356 pp.

Gagné 2018. Key to Adults of North American Genera of the Subfamily Cecidomyiinae (Diptera: Cecidomyiidae). Zootaxa 4392: 401-457.

Gagné, R.J. and M. Jaschhof. 2017. A Catalog of Cecidomyiidae of the World. $4^{\text {th }}$ Edition. Digital. 762 pp. https://www.ars.usda.gov/ARSUserFiles/ 80420580/Gagne_2017_World_Cat_4th_ed. pdf.

Kolesik, P. and G. Baker. 2013. New species of Resseliella (Diptera: Cecidomyiidae), injurious to Dianella and Phormium (Xanthorrhoeaceae) in Australia and New Zealand. Australian Journal of Entomology 52: 6772.

Möhn, E. 1955. Beiträge zur Systematik der Larven der Itonididae (=Cecidomyiidae, Diptera). 1. Teil: Porricondylinae und Itonidinae Mitteleuropas. Zoologica 105 (1\&2): 1-247, 30 pls.

Simon C., F. Frati, A. Beckenbach, B. Crespi, H. Liu and P. Flook (1994) Evolution, weighting, and phylogenetic utility of mitochondrial gene sequences and a compilation of conserved polymerase chain reaction primers. Annals of the Entomological Society of America 87: 651-701.

Tamura, K., Stecher, G., Peterson, D., Filipski, A., and Kumar, S. 2013. MEGA6: molecular evolutionary genetics analysis version 6.0. Molecular Biology and Evolution, 30: 27252729.

Yukawa, J. 1971. A revision of the Japanese gall midges (Diptera: Cecidomyiidae). Memoirs of the Faculty of Agriculture, Kagoshima University 8: 1-203. 